\title{
Voices of peasant farmers from the margins of the global food crisis
}

Book review by Breann Maxwell ${ }^{\mathrm{a}}$ and Zulfiya Tursunova ${ }^{\mathrm{b}}$ University of Manitoba

\section{Hungty for Change: Farmers, Food Justice and the Agrarian Question}

Akram-Lodhi, A H. (2013). Hungry for change: Farmers, food justice and the agrarian question. Black Point, Nova Scotia: Fernwood Publishing, 200 pages. Available as paperback. Publisher's website: http:// fernwoodpublishing.ca/Hungry-for-Change/

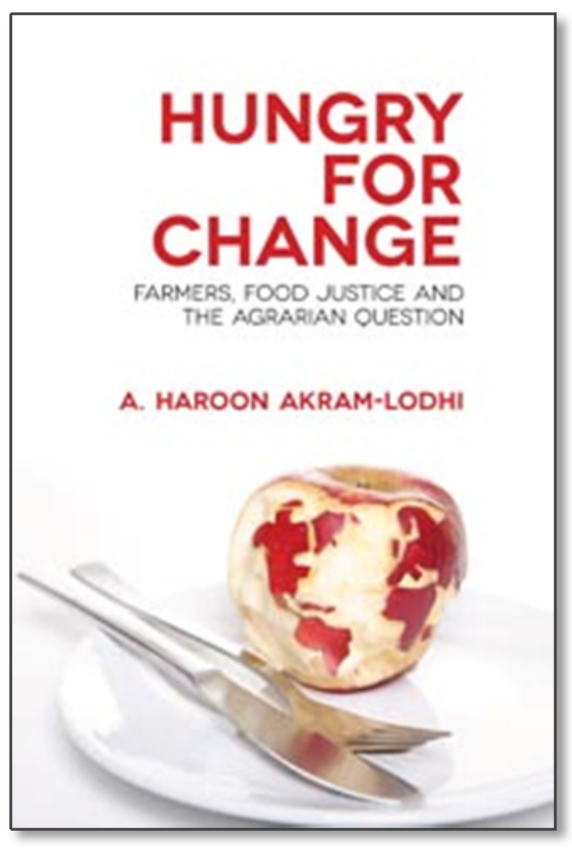

Published online May 5, 2014

Citation: Maxwell, B., \& Tursunova, Z. (2014). Voices of peasant farmers from the margins of the global food crisis [Book review of Hungry for Change: Farmers, Food Justice and the Agrarian Question]. Journal of Agriculture, Food Systems, and Community Development, 4(3), 213-215. http://dx.doi.org/10.5304/jafscd.2014.043.005

Copyright (C) 2014 by New Leaf Associates, Inc.

$\mathrm{H}$ aroon Akram-Lodhi's Hungry for Change:

Farmers, Food Justice and the Agrarian Question adds to the growing literature on food sovereignty and social movements from around the globe. The books Food Sovereignty in Canada: Creating Just and Sustainable Food Systems (2011) and Food Sovereignty: Reconnecting Food, Nature and Community (2010), written by scholars and agrarian activists and edited by Hannah Wittman, Annette Aurelie Desmarais, and Nettie Wiebe, detail the origins of food sovereignty and analyze food regimes and food crises. The authors outline agrarian reforms from historical and contemporary perspectives and explain the relationships between food systems, energy, climate change, environment, and food

a Breann Maxwell, MA, student in Peace and Conflict Studies, University of Manitoba; ummaxw28@myumanitoba.ca

b Dr. Zulfiya Tursunova, Women's and Gender Studies, University of Manitoba; zulfiya.tursunova@umanitoba.ca regime restructuring. Through an examination of socio-economic and environmental consequences of the food system, the authors provide examples of peasant movements that are transforming relationships between food, markets, and local and global communities. Other recent books include Food Regimes and Agrarian Questions by Philip McMichael (2013), Class Dynamics of Agrarian Change by Henry Bernstein (2010), and Peasants and the Art of Farming: A Chayanovian Manifesto by Jan Douwe van der Ploeg (2013). These scholars focus on the structure and dynamics of peasant farms, production and labor, and consistent marginalization of peasants as result of liberalization and globalization. Such books as Food for Thought: A Multidisciplinary Discussion by Robert Stewart and Susan Korol (2012) and Food for Change: The Politics and $V$ alues of Social Movements by Jeff Pratt and Pete Luetchford (2013) seek to address food production, distribution, and food choices people make in 
order to show how important alternative food movements are in creating an economic system within which individuals know where, how, and by whom their food is produced.

These influential authors address food sovereignty issues from a systemic perspective to help their readers understand the complex relationships between agriculture, market, laws, and environment and their influences on each other both locally and on a global scale. Building on these and other books, Akram-Lodhi's Hungry for Change puts a human face on agricultural development by examining the socio-economic transformations in individual peasant farmers' lives and the lives of their families as a segment of a bigger global picture. Akram-Lodhi's approach is especially useful as an introduction for readers who wish to understand the devastating effects of the global food regimes on the lives of individuals, especially in the global South. Through personal accounts of peasant farmers, the author fills a niche in the literature by examining the process by which the world food system has become a capitalist enterprise in the hands of power holders, corporations, the IMF and World Bank, and privileged consumers in the North. In the process of creating such a wide-scale food system, those who are producing the food family farmers, peasant farmers, and landless rural workers - are becoming increasingly marginalized while corporations are earning larger profits. Akram-Lodhi identifies the irony of the current global substance crisis: those producing the majority of the world's food are often going hungry while many in the West are suffering from obesity due to their high-calorie intake and yet nutrientdeficient diets.

In the nine chapters of his book, Akram-Lodhi covers a range of topics that help the reader develop a sound understanding of the issues at hand. In chapter one, Akram-Lodhi offers a detailed account of how money has transformed the exchange of goods and services and the complex modes and methods of social reciprocity. The accelerated use of money to purchase food in globalized markets and the expansion of food choices meeting customers' perceptions of the standard of uniformity, color, size, and texture year-round have severe implications for those farmers who produce food, but cannot afford to consume it. In chapter two, the author analyzes how small-scale farmers working as a part of a much larger capitalist economic system are "compelled" to expand their operations and reduce costs in order to survive in the new capitalist food regime. Akram-Lodhi argues that farmers face false choices, being compelled to sell and seek out profits when the profits are uncertain in the market and oligopolies restrict competition.

In chapter three, Akram-Lodhi explains how rural landscapes and farming systems were reconfigured in the global economy in order to produce higher yields for export, which resulted in "foodbased deprivation." This deprivation is the outcome of the market system's coercion: forcing farmers to sell their entire crop to generate money. In this case the agrarian question is dealt with through capitalist relations of production leading to the farmers' dispossession of land.

In chapter four, the author describes the resistance strategies used by peasants in an effort to fight against the transformations in agriculture created by capitalist markets. The evidence suggests that distributive land reforms that favored the poor were often curtailed by the increased control of land by the rural elite in the global South. Furthermore, capitalist markets were transforming farming and agricultural practices at the expense of peasant farmers and the impeding effects of the Green Revolution. Chapter five further develops an analysis of the devastating effects of the Green Revolution; these include an increasingly widespread wealth disparity and deepening inequalities across "developing" capitalist countries.

Chapters six and seven showcase Bob Miller, a fourth-generation rice farmer in Louisiana, and Maxime Auxialaire, who farmed rice for decades in Haiti. The structural adjustment program in Haiti led to trade liberalization and opening of the market to international trade when subsidized U.S. rice invaded local markets and destabilized the livelihood of farmers like Auxialaire. These examples reveal the "predatory role of the capitalist state in establishing a global food regime that undermined peasant and family farming...to the benefit of the large-scale capitalist farms and industrial agriculture" (p. 2). Akram-Lodhi explains how societies have been transformed in ways that create export- 
oriented agriculture while simultaneously intensifying the global subsistence crisis.

Chapter eight shows two incompatible visions for a way out of this crisis. The first is advocated by the World Bank and calls for further developing the capitalism of agriculture. The second is led by a global peasant movement called La Via Campesina. They suggest the need for food sovereignty, a local and sustainable food system that produces abundant, nutritious, and culturally appropriate food produced through ecologically sustainable methods. The heart of this paradigm is to reclaim decision-making power in the food system, focus policies on people's need for food, build knowledge and skills, work with nature, value food providers, localize food systems to build self-sufficiency, and localize control.

In addition to farmers Miller and Auxialaire, Hungry for Change reflects the stories of several characters: Pervaiz Qazi of India, Sam Namimisi, a small-scale Ugandan coffee farmer, and Jessica Carson, a Canadian university student. The use of personal narrative eliminates the isolating effect that theory-rich texts with academic language can have. These first-person testimonies make the alarming statistics all the more powerful, adding a personal connection to issues that can seem beyond any one person's control. Akram-Lodhi's use of storytelling privileges and validates the knowledge of some of the many people who are becoming marginalized by the capitalist global food system. In one especially useful example of participants' personal stories, Akram-Lodhi describes the relationship between Sam Namimisi and Jessica Carson. Jessica lives in a university residence, and like many other universities across Canada, Jessica's university food service holds a contract with Aramark. Akram-Lodhi explains:

Aramark's coffee is a blend designed...by a coffee supplier to have a specific flavour, body and aroma. One of the coffee robustas in the blend supplied to Aramark originates in Uganda, so between Jessica Carson's cup of coffee and a small-scale Ugandan coffee farmer...are a series of steps in a food supply chain that serve to get Sam's coffee to Jessica's cup. (p. 27)
Akram-Lodhi describes the process by which money changes hands in this food supply chain: the small-scale farmer (who produces this crop solely for the purpose of income) is paid very little while the consumer pays a lot, "and most of the money ends up in between, in the hands of global food corporations" (p. 30). The author spells out the rise of a capitalist-centered food system in a way that allows readers not only to understand the pertinent issues at hand but also begin to strategize a more people-centered approach to sustenance.

Akram-Lodhi also provides historical analysis that helps the reader understand the context in which the current food system has evolved. He concisely describes how historical practices have created and continue to influence the way in which we go about growing and consuming food. A series of well intentioned "upgrades," like selling food for currency rather than trading in a barter system, the mechanization of agriculture, the introduction of chemicals, the creation of GMOs, etc., all of which were intended to produce surplus to help feed more people, have in fact worked together to create a world in which hunger and obesity are occurring simultaneously. Removing nature and personal connections from food production has led us to this point; Akram-Lodhi suggests that it seems only logical that the way out of this unsustainable system is to return to small-scale farming, challenging the power of the market imperative and reconstructing food as a public good.

Taken as a whole, Akram-Lodhi's research contributes strongly through the voices of farmers to understanding the challenges in implementing food sovereignty principles. He informs his readers about the importance of acting both locally and globally in developing sustainable agricultural and environmental systems that benefit the many rather than the few. This book is good for students specializing in development studies as well as the general public. In order to develop solutions to the global problems created by the current food system we must first understand what has brought us to this point; Akram-Lodhi's work provides valuable insight that is necessary to begin to this process of understanding. 